\title{
Kejang Berulang dan Status Epileptikus pada Ensefalitis sebagai Faktor Risiko Epilepsi Pascaensefalitis
}

\author{
Nur Laili Muzayyanah, Sunartini Hapsara, Tunjung Wibowo \\ Bagian Ilmu Kesehatan Anak Fakultas Kedokteran Universitas Gadjah Mada/RSUP Dr. Sardjito, \\ Yogyakarta
}

Latar belakang. Epilepsi pascaensefalitis merupakan salah satu komplikasi ensefalitis yang sering terjadi serta memerlukan tata laksana jangka panjang dan menurunkan kualitas hidup pasien. Kejang berulang dan status epileptikus pada ensefalitis dicurigai dapat meningkatkan risiko terjadi epilepsi pascaensefalitis.

Tujuan. Mengetahui apakah risiko epilepsi pascaensefalitis lebih tinggi pada pasien yang mengalami kejang berulang dan status epileptikus pada ensefalitis.

Metode. Penelitian kasus kontrol pada pasien pascaensefalitis usia 6 bulan-18 tahun dilakukan di bangsal anak RSUP Dr. Sardjito, Yogyakarta. Kelompok kasus terdiri dari 26 pasien dengan diagnosis epilepsi pascaensefalitis, 27 pasien pascaensefalitis dengan gejala sisa selain epilepsi atau tanpa gejala sisa sebagai kelompok kontrol. Data klinis subyek selama episode ensefalitis akut didapatkan dari rekam medis pasien saat dirawat. Kekuatan hubungan antara variabel independen dengan variabel dependen diketahui berdasarkan analisis bivariat dan analisis multivariat.

Hasil. Kejang berulang ensefalitis akut meningkatkan risiko terjadinya epilepsi pascaensefalitis (OR 3,6;95 $\%$ CI 1,0-12,7; p<0,05). Status epileptikus ensefalitis secara klinis meningkatkan risiko terjadinya epilepsi pascaensefalitis, tetapi secara statistik tidak bermakna (OR 2,4;95\% CI 0,7-8,2; p>0,05).

Kesimpulan. Kejang berulang ensefalitis meningkatkan risiko terjadinya epilepsi pascaensefalitis. Status epileptikus pada ensefalitis secara klinis meningkatkan risiko terjadinya epilepsi pascaensefalitis, tetapi secara statistik tidak bermakna. Sari Pediatri 2013;15(3):150-5.

Kata kunci: kejang berulang, status epileptikus, epilepsi pascaensefalitis

\footnotetext{
Alamat korespondensi:

Dr. Nur Laili Muzayyanah,Sp.A. Bagian Ilmu Kesehatan Anak, Fakultas Kedokteran Universitas Gadjah Mada/RSUP. Dr.Sardjito, Jalan Kesehatan No. 1 Sekip Yogyakarta 55284, Indonesia. Telp. (0274) 561616, Fax. (0274) 583745. E-mail: nur_laili@idai.or.id
}

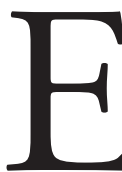

nsefalitis adalah infeksi akut pada parenkim otak dengan karakteristik klinis demam tinggi, nyeri kepala, dan penurunan kesadaran. Gejala lain yang mungkin adalah defisit neurologis fokal atau multifokal, dan kejang fokal atau general (menyeluruh). Infeksi pada susunan saraf pusat dapat menyebabkan epilepsi $1 \%-5 \%$ dari semua kasus epilepsi. Insiden epilepsi tertinggi pada 5 tahun 
pertama setelah infeksi susunan saraf pusat. Patogenesis epilepsi tersebut masih belum diketahui pada sebagian besar kasus epilepsi pascaensefalitis. ${ }^{2}$

Faktor risiko terjadinya epilepsi pascaensefalitis adalah kejang berulang, status epileptikus, penurunan kesadaran yang berat, adanya tanda neurologis fokal dan deteriorasi neurologis selama ensefalitis akut. Pasien dengan status epileptikus refrakter meningkatkan risiko terjadinya intractable epilepsi pascaensefalitis. Oleh karena itu, epilepsi pascaensefalitis merupakan komplikasi yang sering terjadi pada ensefalitis akut. ${ }^{3}$

Tipe infeksi susunan saraf pusat dan kejang yang terjadi pada ensefalitis akut merupakan faktor risiko bermakna untuk terjadinya epilepsi pascaensefalitis. ${ }^{2}$ Anak yang mengalami kejang mempunyai risiko lebih tinggi untuk menderita epilepsi pascaensefalitis dibandingkan dengan anak yang tidak mengalami kejang pada ensefalitis akut. Kejang yang berkepanjangan pada ensefalitis akut juga merupakan faktor risiko yang penting untuk terjadinya epilepsi pascaensefalitis. ${ }^{4}$ Kejang berulang yang terjadi pada ensefalitis akut berhubungan dengan prognosis yang buruk, mempunyai denyut jantung yang lebih cepat, memerlukan tindakan intubasi, mempunyai Pediatrics coma scale rata-rata yang lebih rendah dan menunjukkan tanda-tanda abnormalitas motorik seperti abnormalitas tonus otot, refleks ekstremitas abnormal, dan kelemahan ekstremitas. ${ }^{5}$

Epilepsi pasca ensefalitis merupakan salah satu komplikasi dari ensefalitis yang sering terjadi, serta memerlukan tata laksana jangka panjang dan menurunkan kualitas hidup pasien. Oleh karena itu, perlu dikaji faktor risiko epilepsi pascaensefalitis, yaitu kejang berulang dan status epileptikus yang terjadi pada ensefalitis akut.

\section{Metode}

Penelitian observasional retrospektif, dengan rancang bangun kasus kontrol dilaksanakan dalam periode Januari 2011 sampai Maret 2011. Penelitian bertempat di poliklinik neurologi dan bagian keperawatan anak (bangsal, PICU) RSUP DR. Sardjito, Yogyakarta. Subyek penelitian dikelompokkan menjadi dua kelompok, yaitu kelompok kasus dan kelompok kontrol. Kelompok kasus adalah pasien usia 6 bulan 18 tahun yang datang ke poliklinik neurologi dengan diagnosis epilepsi pascaensefalitis, tidak terdapat gangguan neurologis sebelum menderita ensefalitis dan tidak terdapat riwayat kejang tanpa demam sebelum ensefalitis. Diagnosis epilepsi pascaensefalitis ditegakkan berdasarkan gejala klinis adanya kejang fokal maupun general tanpa demam setelah menderita ensefalitis, dan pemeriksaan EEG. Kelompok kontrol adalah pasien usia 6 bulan - 18 tahun yang datang ke poliklinik neurologi dengan diagnosis pascaensefalitis dengan gejala sisa selain epilepsi atau tanpa gejala sisa, tidak terdapat gangguan neurologis sebelum menderita ensefalitis dan tidak terdapat riwayat kejang tanpa demam sebelum ensefalitis. Diagnosis ensefalitis ditegakkan berdasarkan gambaran klinis ensefalitis, yaitu demam tinggi, nyeri kepala, penurunan kesadaran, kejang fokal atau general, defisit neurologis fokal atau multifokal dan didukung oleh pemeriksaan cairan serebrospinal. Subyek yang tidak dirawat di RSUP Dr. Sardjito sewaktu menderita ensefalitis, data rekam medis pasien tidak lengkap dan tidak bersedia ikut serta dalam penelitian tidak diikutsertakan dalam penelitian. Pengamatan kejang berulang dan status epileptikus pada ensefalitis sebagai faktor risiko epilepsi pascaensefalitis dilakukan secara retrospektif melalui data sekunder, yaitu rekam medis pasien ensefalitis yang dirawat inap dengan menggunakan formulir penelitian.

Perkiraan besar sampel dihitung berdasarkan rumus untuk studi kasus kontrol tidak berpasangan. Menurut Sastroasmoro dan Ismael ${ }^{6}$ ditetapkan besar sampel yang digunakan adalah 26 sampel untuk masing-masing kelompok kasus dan kontrol. Cara pengambilan sampel yang digunakan dengan cara berurutan (consecutive sampling). Pemilihan kelompok kontrol dilakukan tanpa matching.

Data yang diperoleh diuji dengan analisis tabulasi silang (uji chi square). Hubungan antar variabel bebas dan variabel yang paling berpengaruh terhadap risiko terjadinya epilepsi pascaensefalitis diketahui berdasarkan analisis multivariat dengan regresi logistik. Hubungan yang kuat antara variabel independen dengan variabel dependen dinyatakan dengan OR. Tingkat kemaknaan yang diinginkan jika $\mathrm{p}<0,05$ dan interval kepercayaan 95\% tidak melewati angka 1.

\section{Hasil}

Berdasarkan kriteria inklusi dan eksklusi didapatkan 53 anak usia 6 bulan-18 tahun, terdiri dari 26 subyek 
epilepsi pascaensefalitis (kelompok kasus) dan 27 subyek pascaensefalitis dengan gejala sisa selain epilepsi atau tanpa gejala sisa (kelompok kontrol).

Karakteristik subyek penelitian tertera pada Tabel 1. Berdasarkan umur, sebagian besar subyek dalam kelompok umur 6 bulan- 5 tahun $(77,4 \%)$. Berdasarkan jenis kelamin, pada kelompok kasus, jumlah laki-laki sama dengan perempuan, sedangkan pada kelompok kontrol, laki-laki lebih banyak dari perempuan (70\%).

Tabel 2 menunjukkan analisis bivariat dan multivariat kejang berulang dan status epilepti-

Tabel 1. Karakteristik dasar subyek

\begin{tabular}{lcc}
\hline & \multicolumn{2}{c}{ Jumlah } \\
\cline { 2 - 3 } Variabel & Kasus & Kontrol \\
& $\mathrm{n}(\%)$ & $\mathrm{n}(\%)$ \\
\hline Usia & & \\
$\quad 6$ bulan-5 tahun & $22(85)$ & $19(70)$ \\
$\quad$ 6-18 tahun & $4(15)$ & $8(30)$ \\
Jenis kelamin & & \\
$\quad$ Laki-laki & $13(50)$ & $19(70)$ \\
$\quad$ Perempuan & $13(50)$ & $8(30)$ \\
Kejang berulang & & \\
$\quad$ Ya & $20(77)$ & $11(40)$ \\
Tidak & $6(23)$ & $16(60)$ \\
Status epileptikus & & $9(33)$ \\
$\quad$ Ya & $16(61)$ & $18(67)$ \\
Tidak & $10(39)$ & $12(44)$ \\
PCS score* & & $15(56)$ \\
$\leq 8$ & $16(61)$ & $13(48)$ \\
$>8$ & $10(39)$ & $14(52)$ \\
Deteriorasi neurologis & & \\
Ya & $10(39)$ & $16(61)$ \\
Tidak & & \\
\hline
\end{tabular}

*PCS= pediatric coma scale kus pada ensefalitis sebagai faktor risiko epilepsi pascaensefalitis. Variabel bebas dengan nilai $\mathrm{p}<0,2$ pada analisis bivariat, yaitu jenis kelamin laki-laki, kejang berulang, dan status epileptikus diikutsertakan dalam analisis multivariat. Berdasarkan analisis bivariat, pasien ensefalitis dengan kejang berulang mempunyai risiko 4,9 kali lebih tinggi untuk menderita epilepsi pascaensefalitis dan secara statistik bermakna (95\% CI 1,5-16,0; $\mathrm{p}<0,05)$. Setelah dikontrol oleh variabel independen lain dengan analisis multivariat, kejang berulang tetap bermakna meningkatkan risiko terjadinya epilepsi pascaensefalitis (OR 3,6; 95 \% CI 1,0-12,7; $\mathrm{p}<0,05)$. Pada analisis bivariat, pasien dengan status epileptikus mempunyai risiko 3,2 kali lebih tinggi untuk menderita epilepsi pascaensefalitis dan bermakna secara statistik (95\% CI 1,0-9,9; $\mathrm{p}<0,05)$, tetapi setelah dikontrol oleh variabel independen lain dengan analisis multivariat, status epileptikus pada ensefalitis secara klinis meningkatkan risiko terjadinya epilepsi pascaensefalitis, tetapi secara statistik tidak bermakna (OR 2,4; $95 \%$ CI 0,7-8,2; p>0,05). Usia, jenis kelamin, penurunan kesadaran yang berat dan deteriorasi neurologis bukan merupakan faktor risiko epilepsi pascaensefalitis.

\section{Pembahasan}

Hasil penelitian kami sesuai dengan penelitian sebelumnya yang mendapatkan bahwa anak yang menderita kejang pada ensefalitis mempunyai risiko 8 kali untuk berkembang menjadi epilepsi pascaensefalitis (95\%CI:1,04-64,60;p<0,05).7 Semua pasien epilepsi pascaensefalitis ( 42 pasien) berhubungan dengan

Tabel 2. Analisis bivariat dan multivariat penelitian kejang berulang dan status epileptikus

\begin{tabular}{lcccccc}
\hline \multirow{2}{*}{ Variabel } & \multicolumn{3}{c}{ Bivariat } & \multicolumn{3}{c}{ Multivariat } \\
\cline { 2 - 7 } & OR & $95 \% \mathrm{CI}$ & $\mathrm{p}$ & OR & $95 \% \mathrm{CI}$ & $\mathrm{p}$ \\
\hline Usia 6 bulan - 5 tahun & 2,3 & $0,6-8,9$ & 0,215 & - & - & - \\
Jenis kelamin laki-laki & 0,4 & $0,1-1,3$ & 0,130 & 0,4 & $0,1-1,5$ & 0,188 \\
Kejang berulang & 4,9 & $1,5-16$ & 0,008 & 3,6 & $1,0-12,7$ & 0,047 \\
Status epileptikus & 3,2 & $1,0-9,9$ & 0,040 & 2,4 & $0,7-8,2$ & 0,168 \\
PCS score $\leq 8$ & 2 & $0,7-6,0$ & 0,213 & - & - & - \\
Deteriorasi neurologis & 0,7 & $0,2-2,0$ & 0,477 & - & - & - \\
\hline
\end{tabular}


episode ensefalitis berat yang diderita sebelumnya. Tigapuluh tiga $(79 \%)$ pasien mengalami status epileptikus atau kejang berulang selama periode akut penyakit. Penurunan kesadaran terjadi pada 32 (76 \%) pasien, termasuk 26 (62\%) pasien dengan koma dalam. Tidak terdapat periode laten antara onset kejang berulang dengan ensefalitis pada mayoritas pasien (32/42). Sepuluh (24\%) pasien kejang tanpa provokasi pertama terjadi antara 2 bulan dan 8 tahun (median 3 tahun) setelah menderita ensefalitis. Rerata periode laten 42 pasien adalah 0,8 tahun. ${ }^{8}$

Mekanisme tubuh yang terjadi selama kejang adalah terjadi peningkatan aliran darah ke otak, konsumsi gula dan oksigen, serta peningkatan produksi karbondioksida dan asam laktat. Perubahan sistemik awal meliputi takikardi, hipertensi, hiperglikemia, dan hipoksemia. Kejang yang singkat jarang menimbulkan pengaruh terhadap otak, tetapi kejang yang lama dapat menimbulkan asidosis laktat, rabdomiolisis, hiperkalemia, hipertermi, dan hipoglikemi yang berhubungan dengan kerusakan neurologis permanen. Tata laksana jalan napas dan menghentikan kejang adalah prioritas utama pada pasien dengan kejang. ${ }^{9}$

Kami mendapatkan bahwa status epileptikus yang terjadi pada ensefalitis secara klinis meningkatkan risiko epilepsi pascaensefalitis, tetapi secara statistik tidak bermakna. Hasil tersebut berbeda dengan penelitian yang dilakukan oleh Chen $\mathrm{dkk}^{4}$ yang mendapatkan status epileptikus pada ensefalitis sebagai faktor risiko terjadinya epilepsi pascaensefalitis yang refrakter (OR 16; 95\% CI:1,84-140,2; $<<0,005)$. Status epileptikus biasanya berhubungan dengan penurunan kesadaran dan penggambaran keparahan ensefalitis, dapat mengakibatkan kerusakan struktur cortical dan hippocampal yang menyebabkan epilepsi lobus mesial-temporalyang biasanya refrakter terhadap pengobatan. ${ }^{10}$

Jenis kelamin bukan merupakan faktor risiko epilepsi pascaensefalitis. Berbeda dengan penelitian yang dilakukan oleh Fowler $\mathrm{dkk}^{7}$ yang mendapatkan jenis kelamin perempuan mempunyai risiko 5 kali untuk terjadinya epilepsi pascaensefalitis $(95 \%$ CI:1,02-23,40; $\mathrm{p}<0,05)$.

Pada penelitian kami deteriorasi neurologis dan penurunan kesadaran yang berat bukan merupakan faktor risiko terjadinya epilepsi pascaensefalitis. Hasil tersebut berbeda dengan penelitian kohort retrospektif yang dilakukan oleh Lee dkk terhadap 330 anak usia 0-17 tahun dengan diagnosis epilepsi pascaensefalitis yang mendapatkan faktor risiko yang bermakna meliputi kejang berulang, status epileptikus, penurunan kesadaran yang berat, tanda neurologis fokal, dan deteriorasi neurologis yang terjadi selama ensefalitis akut. Perkembangan 330 anak, 54 (16,4\%) menjadi epilepsi dengan rerata periode follow up $6 \pm 4,6$ tahun, dan $79,6 \%$ terdiagnosis epilepsi dalam 6 bulan setelah ensefalitis. Anak dengan status epileptikus refrakter pada periode ensefalitis juga secara bermakna meningkatkan risiko intractable epilepsi pascaensefalitis. ${ }^{3}$

Lin $\mathrm{dkk}^{1}$ melakukan pemantauan selama 6 bulan-51 bulan terhadap 46 pasien ensefalitis usia 8 bulan-16 tahun, mendapatkan bahwa pasien dengan status epileptikus pada saat ensefalitis mempunyai luaran 4 meninggal, 16 berkembang menjadi epilepsi dan atau defisit neurologis dan 6 kembali normal. Pada pasien ensefalitis dengan status epileptikus refrakter dipunyai luaran 6 meninggal, 13 berkembang menjadi epilepsi dan atau defisit neurologis, dan tak satupun kembali normal. Hal tersebut menunjukkan status epileptikus yang berhubungan dengan ensefalitis mempunyai mortalitas dan morbiditas yang tinggi.

Insiden status epileptikus yang terjadi pada ensefalitis anak sekitar 3,8\%-13,7\%. ${ }^{11}$ Ensefalitis merupakan kasus tersering memerlukan perawatan intensif di rumah sakit. Anak-anak ini mempunyai riwayat demam akut dan dengan cepat berkembang menjadi status epileptikus. ${ }^{12}$ Empatpuluh enam pasien ensefalitis dengan status epileptikus, 20 pasien $(43,4 \%)$ berkembang menjadi status epileptikus refrakter (RSE: refractory status epilepticus). RSE adalah kejang yang berlangsung $>2$ jam, meskipun telah diberikan terapi obat antiepilepsi konvensional, meliputi terapi awal dengan golongan benzodiazepine, diikuti dengan dosis terapi fenitoin dan fenobarbital. Status epileptikus yang terjadi pada ensefalitis mempunyai risiko yang sangat tinggi untuk berkembang menjadi $R S E$.

Ensefalitis dengan status epileptikus mempunyai mortalitas dan morbiditas yang tinggi. Hal tersebut karena status epileptikus dapat mengakibatkan komplikasi sistemik, seperti disritmia jantung, gangguan metabolik dan fungsi otonom, edema paru neurogenik, hipertermi, rabdomiolisis, dan aspirasi paru. Kerusakan neurologis permanen pada ensefalitis dengan aktifitas kejang yang tidak terkontrol dan berkepanjangan dapat disebabkan oleh invasi virus langsung, respon imun pasien yang teraktivasi oleh pathogen, atau kematian neuron yang diinduksi oleh status epileptikus. ${ }^{13}$ Durasi yang panjang dari status 
epileptikus berhubungan dengan luaran neurologis yang buruk, terutama terjadinya epilepsi setelah terjadi status epileptikus pada ensefalitis. ${ }^{14,15}$

Status epileptikus atau kejang berulang atau epilepsi pascaensefalitis adalah faktor risiko terjadi kehilangan parenkim otak yang lebih besar. Beberapa penelitian terhadap binatang mendapatkan hilangnya neuron yang dapat diukur setelah terjadi status epileptikus yang diinduksi oleh obat. ${ }^{16,17}$ Pada manusia, penelitian tentang pemantauan neuropatologi dan MRI setelah terjadi status epileptikus ditunjukkan hilangnya parenkim di hippocampus, ${ }^{18}$ juga di daerah otak lain seperti thalamus, striatum, clustrum, serebelum dan atau korteks. ${ }^{19,20}$ Mekanisme penyebab kerusakan neuron yang diinduksi oleh status epileptikus adalah pelepasan glutamat yang berlebihan dan akhirnya menyebabkan kematian sel.$^{21}$

Sebuah penelitian MRI terbaru menunjukkan atrofi neocortical fokal dan menyeluruh pada pasien dengan epilepsi kronis. ${ }^{22}$ Atrofi serebral difus parsial pada pasien dengan epilepsi pascaensefalitis (sebagian besar dengan kejang parsial kompleks) didapatkan pada penelitian dengan 42 pasien. ${ }^{8}$ Sebagian besar pasien $(79 \%)$ mengalami kejang berulang atau status epileptikus pada periode ensefalitis. Namun, belum dapat ditentukan dengan pasti apakah status epileptikus pada saat ensefalitis atau epilepsi pasca ensefalitis yang mempunyai faktor risiko yang lebih besar untuk terjadi kehilangan parenkim otak. ${ }^{23}$

Hermann dkk $^{23}$ tidak mendapatkan hubungan antara kehilangan parenkim otak dengan agen penyebab ensefalitis yang spesifik, keparahan gangguan kesadaran atau faktor-faktor klinis lain yang menunjukkan keparahan penyakit akut. Kehilangan parenkim otak berhubungan dengan terjadinya kejang pada ensefalitis dan efek ini mungkin diperkuat dengan terjadinya kejang epileptik setelah periode ensefalitis akut.

Epilepsi pascaensefalitis terjadi paling tinggi pada 5 tahun pertama setelah ensefalitis, tetapi masih meningkat pada pemantauan setelah 15 tahun. Tipe infeksi susunan saraf pusat dan adanya kejang pada periode ensefalitis akut merupakan risiko terjadinya kejang tanpa provokasi setelah ensefalitis. Pemantauan selama 20 tahun didapatkan insiden epilepsi 22\% pada ensefalitis virus dengan kejang pada periode akut, $10 \%$ ensefalitis virus tanpa kejang pada periode akut, $13 \%$ meningitis bakterial dengan kejang, dan 2,4\% meningitis bakterial tanpa kejang pada periode akut. $^{2}$
Usia saat ensefalitis, adanya kejang pada awal ensefalitis, panjangnya periode laten (waktu antara onset ensefalitis dengan onset kejang pascaensefalitis) dan parameter cairan serebrospinal bukan merupakan prediktor luaran epilepsi pascaensefalitis. Pengendalian kejang, terutama status epileptikus selama periode ensefalitis akut merupakan hal yang sangat penting untuk memperbaiki luaran, untuk itu perlu dilakukan intervensi lebih dini dan strategi pencegahan kejang. ${ }^{4}$ Pasien epilepsi pascaensefalitis mempunyai pola kejang yang bervariasi dan sering refrakter dengan terapi obat anti epilepsi. ${ }^{24}$ Pasien epilepsi pascaensefalitis mempunyai luaran bedah yang memuaskan jika infeksi terjadi sebelum usia 4 tahun dan jika mesial temporal sclerosis (MTS) dapat diidentifikasi. ${ }^{25}$

Ensefalitis dan meningoensefalitis adalah penyebab catastrophic epilepsy pascaensefalitis. Catastrophic epilepsy (CE) merupakan epilepsi yang sering refrakter terhadap pengobatan dan selalu berhubungan dengan deteriorasi psikoneurologis. Prognosis CE pascaensefalitis ini sangat serius.$^{26}$

Penelitian kami adalah penelitian retrospektif sehingga mempunyai kekurangan untuk lebih jauh menganalisis hubungan sebab akibat, sehingga diperlukan penelitian lebih lanjut dengan menggunakan metode penelitian prospektif. Penggunaan data sekunder rekam medis yang kadang kurang lengkap dan kurang akurat juga dapat menimbulkan bias.

\section{Kesimpulan}

Kejang berulang yang terjadi pada ensefalitis meningkatkan risiko terjadinya epilepsi pascaensefalitis. Status epileptikus pada ensefalitis secara klinis meningkatkan risiko terjadinya epilepsi pascaensefalitis tetapi secara statistik tidak bermakna.

\section{Daftar pustaka}

1. Lin JJ, Lin KL, Wang HS, Hsia SH and Awau CT. Analiysis of status epilepticus related presumed encephalitis in children. Eur J Paediatr Neurol 2008; 12:32-7.

2. Annegers JF, Hauser WA, Beghi E, Nicosi A, Kurland LT. The risk of unprovoked seizures after encephalitis and meningitis. Neurol 1992;42:1513-8.

3. Lee WT, Yu TW, Chang WC, Shau WY. Risk factors for 
postencephalitic epilepsy in children: a hospital based study in Taiwan. Eur J Paediatr Neurol 2007;11:3029.

4. Chen YJ, Fang PC and Chow JC. Clinical characteristics and prognostic factors of postencephalitic epilepsy in children. J Child Neurol 2006; 21:1047-51.

5. Ooi MH, Lewthwaite P, Lai BF. Epidemiology, clinical features and long term prognosis of Japanese encephalitis in Central Sarawak. Malasyia, 1997-2005. Clin Infect Dis 2008;47:458-68.

6. Sastroasmoro S, Ismael S. Dasar-dasar metodologi penelitian Klinis. Edisi 2. Jakarta: CV. Sagung Seto; 2002.

7. Fowler A, Stodberg T, Eriksson M and Wickstrom R. Long-term outcomes of acute encephalitis in childhood. Pediatric 2010;126:e828-34.

8. Trinka E, Dubeau F, Andeman F. Clinical finding, imaging characteristic and outcome in catastrophic postencephalitic epilepsy. Epileptic Dis 2000; 2;3:15362.

9. Friedman MJ, Sharieff GQ. Seizures in children. Pediatr Clin N Am 2006;53:257-77.

10. Pohlmann EB, Gass A and Peters CN Evolution of MRI changes and development of bilateral hippocampal sclerosis during long lasting generalized status epilepticus. J Neurol Neurosurg Psychiatry 2004;75:898-900.

11. Chin RF, Neville BG, Peckham C. Incidence, cause, and short-term outcome of convulsive status epilepticus in childhood: prospective population-based study. Lancet 2006;368:222-9.

12. Sahin M, Menache CC, Holmes GL, Riviello Jr. Prolonged treatment for acute symptomatic refractory status epilepticus: outcome in children. Neurology 2003;61:398-401.

13. Fujikawa DG. Prolonged seizures and cellular injury: understanding the connection. Epilepsy Behav 2005;7: S3-S11.

14. Holtkamp M, Othman J, Buchheim K and Meierkord H. Predictors and prognosis of refractory status epilepticus treated in a neurological intensive care unit. J Neurol
Neurosurg Psychiatry 2005;76:534-9.

15. Maegaki Y, Kutozawa $Y$ and Hanaki KOK. Risk factors for fatality and neurological sequel after status epilepticus in children. Neuropediatrics 2005;36:186-92.

16. Borges K, Gearing $M$ and McDermott DL. Neuronal and glial pathological changes during epileptogenesis in the mouse pilocarpine model. Exp Neurol 2003;182:2134.

17. Wasterlain CG, Denson GF and Penix IR Pathophysiological mechanisms of brain damage from status epilepticus. Epilepsia 1993;34(suppl I):S37-53.

18. DeGiorgo CM, Tomiyasu U and Gott PS Hippocampal pyramidal cell loss in human status epilepticus. Epilepsia 1992;33:23-7.

19. Hong KS, Cho YJ and Lee SK Diffusion changes suggesting predominant vasogenic oedema during partial status epilepticus. Seizure 2004;13:317-21.

20. Nixon J, Bateman D and Moss T. An MRI and neuropathological study of case of fatal status epilepticus. Seizure. 2001;10:588-91.

21. Treiman DM. Will brain damage after status epilepticus be history in 2010?. Prog Brain Res 2002;135:471-8.

22. Liu RS, Lemieux I and Bell GS. Progressive neocortical damage in epilepsy. Ann Neurol 2003;53:312-24.

23. Herrmann EK, Hahn K, Kratzer C, Seggern I, Zimmer C, Schielke, E. Status epilepticus as a risk factor for postencephalitic parenchyma loss evaluated by ventricle brain ratio measurement on MR Imaging. AJNR Am J Neuroradiol 2006;27:1245-51.

24. Ohtsuka Y, Yoshinaga $\mathrm{H}$ and Kobayashi K. Predictors and underlying causes of medically intractable localization-related epilepsy in childhood. Pediatr Neurol 2001;24:209-13.

25. Marks DA, Kim J, Spencer DD, Spencer SS. Characteristics of intractable seizures following meningitis and encephalitis. Neurology 1992;42:15138.

26. Barrera NM. Clinical, neuro-radiological and prognostik aspect of post-encephalitic catasthrophic epilepsies. Rev Neurol 2002;35(Suppl 1):30-8. 